\title{
Destructive attraction: factors that influence hunting pressure on the Blue Bird-of-paradise Paradisaea rudolphi
}

\author{
MICHIEL O. L. VAN DEN BERGH, KOEN KUSTERS and A. J. (TON) DIETZ
}

\begin{abstract}
Summary
The Blue Bird-of-paradise Paradisaea rudolphi (BBOP) is a globally threatened species restricted to the montane rainforest of Papua New Guinea (PNG). Local inhabitants hunt the BBOP for its feathers, which is one of the main reasons for its population decline. The feathers are used for both traditional and commercial purposes. So far virtually nothing is known about which factors enhance or decrease hunting pressure, and how this is influenced by ongoing market integration of local communities. Field research in PNG suggests that the demand for BBOP feathers and, with that, the collection intensity, primarily stem from traditional uses, such as head decoration. Interest in the traditional use of the feathers is particularly high in remote villages, while the value attributed to living birds is higher in less remote villages, suggesting a decrease of BBOP collection intensity with increased market integration. However, increased access to 'outside influences' (namely tourism and Christianity) may both decrease as well as increase hunting pressures. Finally, we argue that awareness-raising among local people, government officials and tourists may well be the most sensible conservation measure.
\end{abstract}

\section{Introduction}

The "Vulnerable" Blue Bird-of-paradise Paradisaea rudolphi (BBOP) is widely known for its eccentric plumage and courtship rituals. Its range is poorly known but likely restricted to lower montane forest $(1,100-2,200 \mathrm{~m})$ in the eastern Central Range of Papua New Guinea (PNG), including the south-eastern and eastern highlands (Beehler et al. 1986, Frith and Beehler 1998, Heads 2002; Figure 1).

Besides habitat loss due to deforestation, hunting is one of the main reasons for its population decline. The birds are collected by local people for their plumes and feathers, for both traditional and commercial use (IUCN 2011).

Birds-of-paradise (BOP), including the BBOP, are an important tourist attraction in PNG, especially for birdwatchers (Van den Bergh unpubl. data). They are protected by law through the Fauna Act of 1966-73, and are listed in CITES Appendix II; commercial sale of any BOP (alive or dead) is therefore prohibited. Limited trade in BOP plumes is legitimately allowed only by PNG citizens and only for customary purposes. Killing of BOP with anything other than traditional means is also prohibited. However, these restrictions are allegedly not enforced and no specific conservation measures have been undertaken for the BBOP (Sekhran and Miller 1996, BirdLife International 2009, CITES 2009, B. Beehler in litt.). Despite legislation to protect BOP from over-exploitation, virtually nothing is known about the actual collection, use and trade in the feathers and plumes, and the threat this entails to BOP species (del Hoyo et al. 2009, Bird in litt., Scholes III in litt.). 

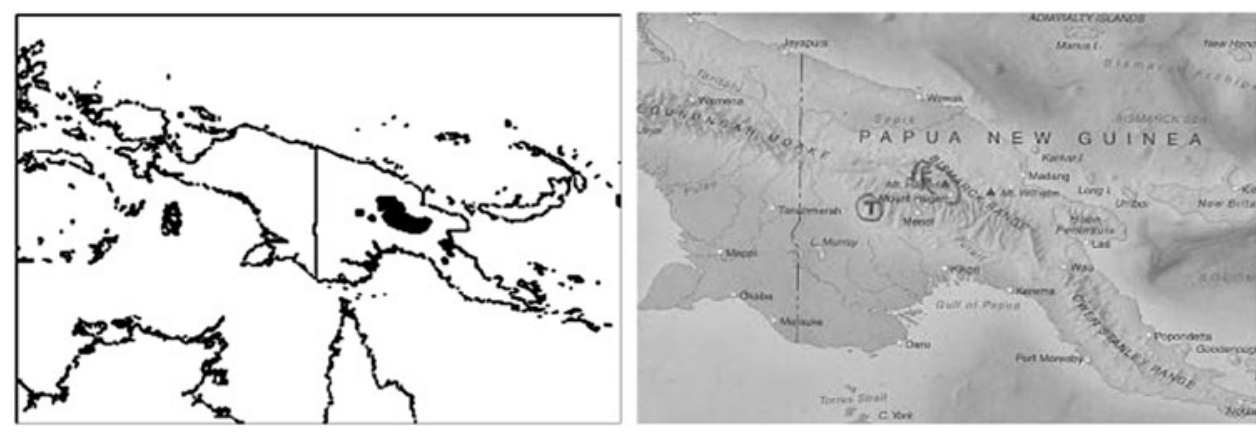

Figure 1. Distribution of the BBOP (left), according to BirdLife International (2009), and (right) location of research areas (circled); Tari research area ( $\mathrm{T}$; left cirle) and Enga research area (E; right circle). International Travel Maps (publication date unknown).

Recently, PNG has been through great social changes. Many inhabitants have moved into the cash economy, and modern tools replaced traditional tools, including the partial replacement of bows and arrows with guns (Kwapena 1984, Connell 1997, IPA 2009). One of the main hypotheses underlying this study is that market access and ongoing integration in commercial markets changes the way in which forest-dependent communities make use of 'forest products' such as the BBOP (Demmer and Overman, 2001).

The paper's first author undertook fieldwork to explore: (i) current hunting practices; (ii) the economic and socio-cultural value of BBOP collection; (iii) the factors enhancing or decreasing hunting pressures and trade; and (iv) the way access to markets and market integration influences collection practices and trade.

\section{Methods}

\section{Study areas}

The Tari and Enga research areas are located in the Central Highlands of the country (see Figure I) and are inhabited by the Huli and Enga ethnic groups respectively. Both ethnic groups have their own language, traditions and customs (see also Tumu et al. 1989, Lomas 1998), but their customs and traditions appear to be rather similar. Each ethnic group is divided into several hundred clans, which is the primary unit of social and political organisation (see also Tumu et al. 1989, Reilly 2008, Goldman 2003). Gregory (1981: 120) defines a clan as "a group of people who own a well defined tract of land and among whom marriage is prohibited".

The Enga research area as a whole has a higher level of market access and integration compared to the Tari research area. The Enga research area has a much larger town (Mount Hagen), many more facilities, a better and more extensively utilised infrastructure, and more than one market town. In contrast to the Tari research area, the Enga research area's inhabitants never wear traditional clothes, more people are employed and adhere to a world religion, and more inhabitants own a modern house. However, due to rugged terrain in the Enga area some of its communities are very remote - more so than the remotest communities in the Tari area, which is a valley that consists of gently rolling hills.

\section{Selection of villages}

In both research areas, five communities were selected, which included the main market town, two non-remote and two remote clan communities. For the analyses it was important to rank the various 
villages in terms of market access and integration. The level of market access was established in each research community by means of three proxies (Table 1 ) and the level of market integration was established by means of nine proxies (Table 2). The proxy data were obtained from male group interviews and where possible verified or invalidated through the researcher's personal observations. For both factors (market access and integration) we ranked each of the proxy variables separately and calculated a mean rank of the proxies for each research area (Table 3 and 4 ). The communities' market access and integration level were correlated and so we ranked communities according to their mean integration and access ranks (Table 5).

\section{Interviews}

Local inhabitants were interviewed by the first author in to communities during 2008. In each of these research communities, semi-structured in-depth interviews were carried out with three groups of individuals: males (three men, > 30), females (three women, >30) and youths (two boys \& two girls, 12-25). As such, a total of 100 respondents were interviewed. In addition to this, several key informants (e.g. policemen, traders, 'clan' leaders, government officials) were interviewed. Where possible, information gathered in these semi-structured interviews was verified or invalidated through literature research, consulting 'experts', observations, market research, and searching for BBOP. Individual and group interviews were aimed at an in-depth understanding of behaviour, values, perceptions and trends, much more than on obtaining exact numbers. The analyses presented in this paper are thus mostly qualitative. A copy of the research questionnaire is provided in the online supplementary materials.

\section{Results}

\section{$B B O P$ values}

The BBOP is valued in many ways. The meat of the birds is used for food, but is fairly insignificant in people's diets, due to low quantities. The meat is almost never a reason to collect the BBOP, and it is never traded. Some people, almost exclusively in the less remote communities, referred to the bird's aesthetic value, mentioning the joy of seeing and hearing these birds. In addition to the aesthetic value, a few Tari research area women ascribe magical power to the possession of feathers, as it allegedly makes men love them. Also, some inhabitants from the Tari research area find the birds' call so clear and strong, that they believe it can strengthen and purify the sound of the 'kundu' drum and bamboo flute. To achieve this effect, a BBOP feather is placed in the middle of the instrument or carefully burnt there in the course of hollowing the drum by fire. Principally, the feathers have significant socio-cultural value, being used as decoration. The feathers are used to decorate household possessions, namely houses and cars (both only by market town inhabitants), but head decoration is by far the most common way of using the feathers. The blue wing feathers are the most valued, although people often use the whole bird, i.e. a bird skin with bill, feet and feathers still attached (Figure 3). The BBOP head decoration is mainly used for 'singsings', which are celebrations that include singing and dancing and which are an important part of the Papua New Guineans' traditions and customs. People decorate themselves for singsings according to their traditional customs, and this usually includes paints, weapons and feathers, and BOP feathers are often the most prominent decorative element (see also Beehler et al. 1986,

Table 1. Proxies for market access.

\begin{tabular}{ll}
\hline Road connection & Distance from the community to the main market town and the condition of the road \\
Public transport & The type, regularity and cost of the public transport \\
Travel time & $\begin{array}{l}\text { The average travel time between the community and the market town by both travel } \\
\text { on foot or by public transport and corrected for their relative frequency of 'use' }\end{array}$ \\
\hline
\end{tabular}


Table 2. Proxies for market integration (a higher number indicates a higher level of market integration).

\begin{tabular}{ll}
\hline $\begin{array}{l}\text { Mobile phone } \\
\text { Modern religion }\end{array}$ & $\begin{array}{l}\text { Percentage of population with a mobile phone } \\
\text { Modern housing }\end{array}$ \\
$\begin{array}{l}\text { Percentage of population adhering to a modern world religion } \\
\text { Percentage of modern houses (versus traditional 'bush' house) } \\
\text { Number of stores in the community }\end{array}$ \\
$\begin{array}{l}\text { Average money amount (in kina) a community member owns (Papua New Guinea } \\
\text { kina (kina or K); exchange rate mid-20o8: } 1 \mathrm{~K}= \pm 0.25 \text { Euro / } 1 \mathrm{~K}= \pm \text { \$o.38 US } \\
\text { (Bank of Papua New Guinea 2009). }\end{array}$ \\
$\begin{array}{l}\text { Percentage of population that masters the language of English } \\
\text { Modern clothing } \\
\text { Market visits }\end{array}$ & $\begin{array}{l}\text { Percentage of population that wears modern ('western') clothes } \\
\text { Average number of market town visits each week per head of the community }\end{array}$ \\
\hline
\end{tabular}

Gascoigne 1998). People may also wear feathers for funerals and tribal fighting, and sometimes the feathers are worn during compensation payment ceremonies (these are held when payments are made to someone who has suffered because of someone else's actions) and other events. In the Tari research area (B)BOP feathers were regularly worn by men for no specific occasion.

In both research areas people use BOP for decoration, but people in Enga attribute specific value to the BBOP as their feathers are among the most highly valued. This is in contrast with the Tari research area, where the BBOP provides one of the least valued BOP feathers. The difference is explained by the inhabitants' historical customs and traditions, which determine the preference of specific BOP species. Substitutes for BBOP feathers in head decoration exist in the Tari research area (mainly other BOP species, including the equally threatened Black Sicklebill Epimachus fastosus), while in the Enga research area most interviewees argued that substitutes do not exist.

The BBOP have both direct and indirect economic value. Directly, people earn money through trade, i.e. selling or renting the feathers. Indirectly, people earn money by participating in singsings, for which the feathers are used, and the feathers are also used in compensation ceremonies as compensation payment. Lastly, free-living wild BBOP attract tourists who may contribute to the local economy.

The economic value of the BBOP appeared relatively low in the Tari research area, and only few inhabitants regard it as important, which is related to the low 'cultural' value, as explained above. In contrast, about half of the Enga interviewees considered the BBOP economically valuable and important, although only few inhabitants benefit from the economic value, and no person is able to solely make a living from just the BBOP's economic value. Inhabitants perceive the value of the BBOP primarily as a collective value.

The trade value was judged as the most important economic value in both research areas, but in the Tari research area the singsing participation value was judged as being equally important. Suggested trade prices of BBOP skins varied greatly, both between and within clans, and ranged between 20 to 50 kina in Tari, and between 5 and 300 kina in Enga (in mid-2008 one kina was

Table 3. Market integration proxies and corresponding values; Tari research area (The percentages are based on observations and estimations made in a group interview with men in each research community).

\begin{tabular}{lcccccccc}
\hline Community & $\begin{array}{l}\text { Mobile } \\
\text { phone }\end{array}$ & $\begin{array}{l}\text { Modern } \\
\text { religion }\end{array}$ & $\begin{array}{l}\text { Modern } \\
\text { housing }\end{array}$ & Stores & $\begin{array}{l}\text { Financial } \\
\text { wealth }\end{array}$ & English & $\begin{array}{l}\text { Modern } \\
\text { clothing }\end{array}$ & $\begin{array}{l}\text { Market } \\
\text { visits }\end{array}$ \\
\hline Tari town & $>25 \%$ & $50 \%$ & $80 \%$ & 11 & 40 & $80 \%$ & $100 \%$ & 5 \\
Pi clan & $3 \%$ & $50 \%$ & $1.2 \%$ & 1 & 100 & $16 \%$ & $100 \%$ & 3 \\
Tikibi clan & $0.5 \%$ & $50 \%$ & $1.9 \%$ & 7 & 50 & $25 \%$ & $>50 \%$ & 2 \\
Munima clan & $0.8 \%$ & $35 \%$ & $0 \%$ & 0 & 20 & $22 \%$ & $75 \%$ & 3 \\
Kawi clan & $2.8 \%$ & $85 \%$ & $1.5 \%$ & 0.5 & 15 & $25 \%$ & $99 \%$ & 1 \\
\hline
\end{tabular}


Table 4. Market integration proxies and corresponding values; Enga research area (The percentages are based on observations and estimations made in a group interview with men in each research community).

\begin{tabular}{lrllllllr}
\hline Community & $\begin{array}{l}\text { Mobile } \\
\text { phone }\end{array}$ & $\begin{array}{l}\text { Modern } \\
\text { religious }\end{array}$ & $\begin{array}{l}\text { Modern } \\
\text { housing }\end{array}$ & Stores & $\begin{array}{l}\text { Financial } \\
\text { wealth }\end{array}$ & English & $\begin{array}{l}\text { Modern } \\
\text { clothing }\end{array}$ & $\begin{array}{l}\text { Market } \\
\text { visits }\end{array}$ \\
\hline Mount Hagen & $10 \%$ & most & $>25 \%$ & many & 35 & $>40 \%$ & $100 \%$ & 5 \\
Wizzy clan & $2 \%$ & $58 \%$ & $24 \%$ & 7 & 12.5 & $13 \%$ & $100 \%$ & $\leq 3$ \\
Pamand clan & $17 \%$ & $81 \%$ & $22 \%$ & 8 & 15 & $17 \%$ & $100 \%$ & 2 \\
Walup clan & $1 \%$ & $83 \%$ & $20 \%$ & 3 & 10 & $33 \%$ & $100 \%$ & $\leq 2$ \\
Anjin clan & $0 \%$ & $83 \%$ & $3 \%$ & 4 & 7.5 & $0 \%$ & $100 \%$ & $<1$ \\
\hline
\end{tabular}

worth $\pm \$ 0.38$ US). Suggested trade prices in Enga research area's non-remote communities were considerably lower than in the remote communities. BBOP are generally sold for higher prices to tourists (up to twice as high). Other BOP species are traded for similar prices in the Enga research area, while in the Tari research area the prices of other BOP species are generally higher.

\section{Collection \& trade}

In the research communities, (B)BOP collection is usually carried out by a small number (4-25) of men. In the market towns of the two research areas virtually no one seemed to be involved in the collection of the birds. Male, female and immature BBOP are seemingly collected indiscriminately. No nestlings or eggs are said to be collected, although an observation during field research suggests otherwise (see Figure 2).

The BBOP are mainly hunted with bows and arrows, but nowadays with guns as well, especially by the young generation in the Tari research area. Slingshots and snare traps are sometimes also used. The birds are mainly hunted by one or a few hunters during general hunting forays or while practising another activity, e.g. gardening. At times men also specifically hunt for BBOP, mainly near fruiting trees where the birds regularly forage for fruits. In the Enga clan communities researched, inhabitants' estimations of the number of BBOP collected by their clan varied between one and 1o BBOP per year. This amount is significantly lower in the Tari clan communities researched, an estimated one bird every 2-10 years. Given estimations differed both between and within clans.

Generally the whole skin of the bird, including the feathers, is traded (Figure 3). There are no specific traders, but trade is done almost exclusively by men. Typically just one or only a couple of skins are traded at a time. A single BBOP is often traded more than once. Most trade takes place between inhabitants of the same clan and/or tribe. Trade occurs at town markets, but also at small community markets and along the roads. Another common way to trade feathers (especially in the Enga research area) is at the buyer's or seller's house, where buyer and seller have met by letting the word out that they want to buy/sell BBOP. On rare occasions, the research area inhabitants trade BBOP in towns outside their tribe's area (as far away as $500 \mathrm{~km}$, such as in the country's capital, Port Moresby).

Table 5. Market access and integration positions.

\begin{tabular}{llllllll}
\hline Tari community & $\begin{array}{l}\text { Market } \\
\text { access }\end{array}$ & $\begin{array}{l}\text { Market } \\
\text { integration }\end{array}$ & $\begin{array}{l}\text { Positions } \\
\text { combined }\end{array}$ & $\begin{array}{l}\text { Enga } \\
\text { community }\end{array}$ & $\begin{array}{l}\text { Market } \\
\text { access }\end{array}$ & $\begin{array}{l}\text { Market } \\
\text { integration }\end{array}$ & $\begin{array}{l}\text { Positions } \\
\text { combined }\end{array}$ \\
\hline Tari town & 1 & 1 & 1 & Mount Hagen & 1 & 1 & 1 \\
Pi clan & 3 & 2 & 2.5 & Wizzy clan & 3 & 3 & 3 \\
Tikibi clan & 2 & 3 & 2.5 & Pamand clan & 2 & 2 & 2 \\
Munima clan & 4 & 5 & 4.5 & Walup clan & 4 & 4 & 4 \\
Kawi clan & 5 & 4 & 4.5 & Anjin clan & 5 & 5 & 5 \\
\hline
\end{tabular}




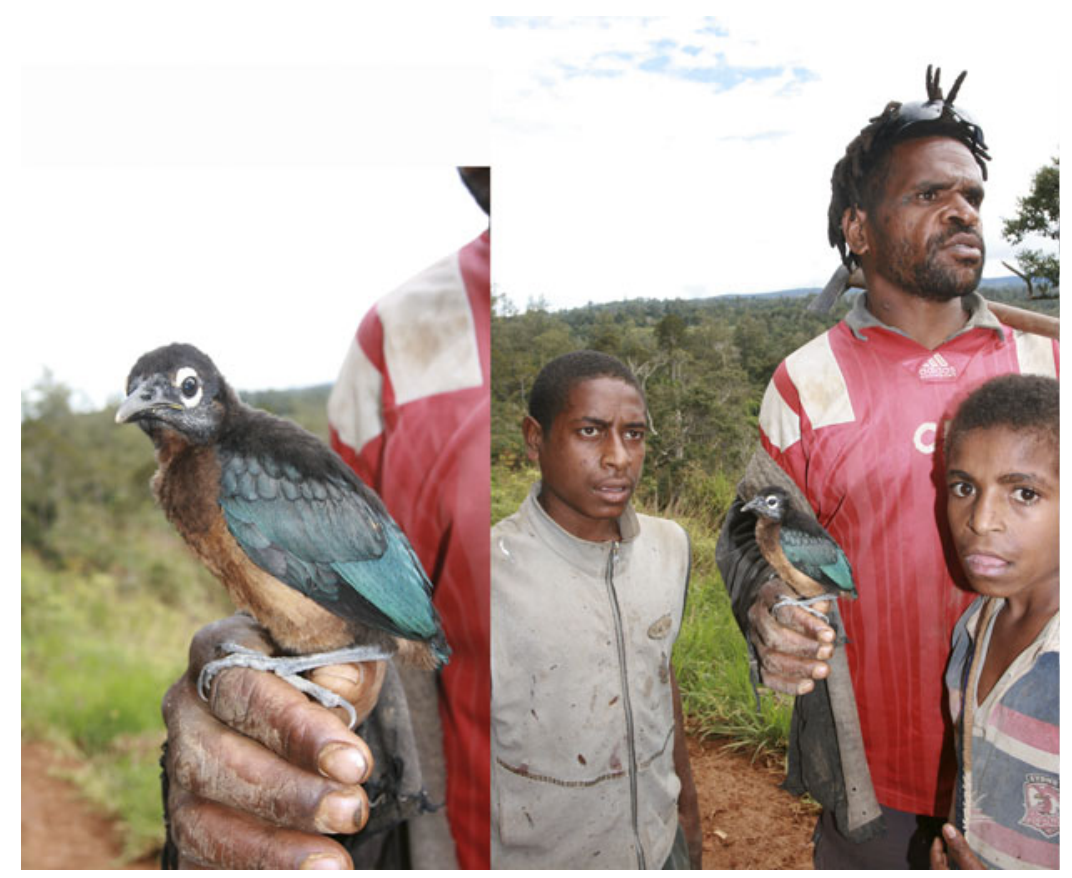

Figure 2. A young BBOP collected from the nest for consumption (Pi clan, Southern Highlands Province, PNG, June 2008; Michiel O. L. van den Bergh).

Next to the trade between inhabitants themselves, on average about a third of the skins are sold to tourists. This sale mainly takes place at the Tari market, at a tourist lodge, at Mount Hagen's airport, and at the cultural showground and hotels in Mount Hagen. BBOP seem to be more regularly traded in the Enga research area than in the Tari research area; between, depending per community, one and nine each year per research community in the Tari research area, while in the Enga research area between one and 20.

\section{Trends and factors influencing hunting pressure}

The results from the group interview suggest that hunting pressure in the Tari region is increasing in several Tari clans. Respondents related this to the increasing number of singsings. This increase is partly explained by new celebrations, such as Independence Day, celebrations related to visits of important people (i.e. politicians), and Christmas. A handful of Tari respondents suggested a decrease in BBOP collection due to less interest in traditions and due a decreasing BBOP population which makes it more difficult to hunt these birds. In the less remote Enga area, on the other hand, the majority of respondents suggested that BBOP collection was decreasing. Some even claimed that the collection in their community had ceased completely. This is largely related to a decreasing number of singsings, which, in turn is explained by a decreasing interest in traditions and an increase in Christianity, which forbids the use of BOP feathers.

BBOP conservation incentives exist due to the economic and socio-cultural value of the birds, although their aesthetic value was probably the strongest incentive in the Enga research area. Some inhabitants indicated that they wanted to use the BBOP sustainably, so they, and future generations, can still benefit from these two values in the future. Similarly, some inhabitants want to preserve the birds for the tourists who want to see these birds and who potentially provide alternative incomes for the inhabitants. Fifty percent of the market town interviewees said they 


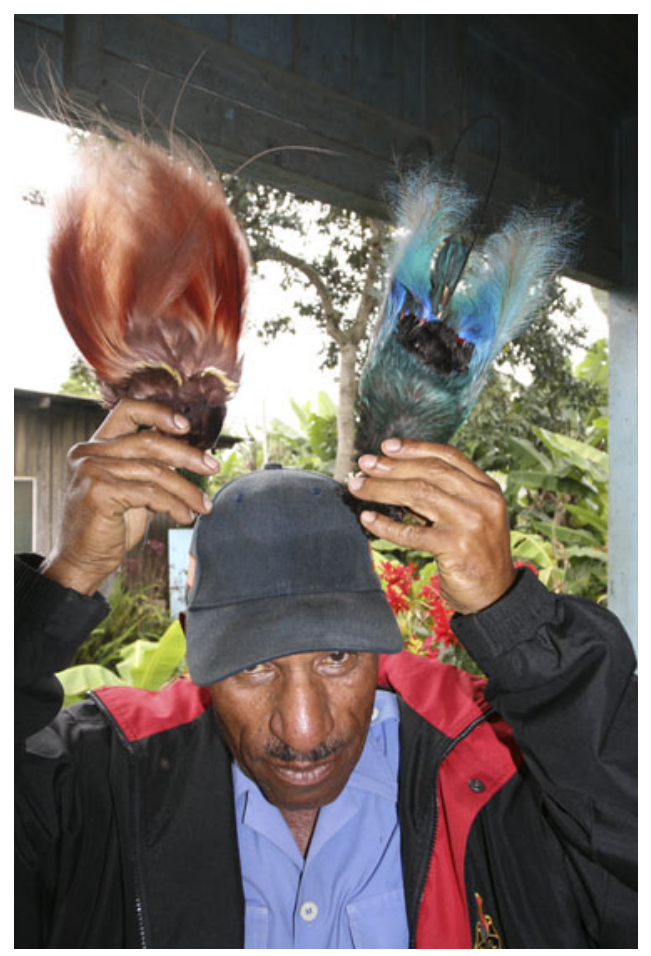

Figure 3. A Mount Hagen policeman showing a Ragianna and Blue Bird-of-paradise skin which he had bought for no particular reason. Does that mean that it was bought for customary purpose or does it mean that it was bought illegally? Either way, the policeman did not seem to care about the (B)BOP trade restrictions at all (Mount Hagen, Southern Highlands Province, PNG, June 2008; Michiel O. L. van den Bergh).

were proud these birds occurred in their area as they are unique to PNG and because BOP are PNG's national symbol. As a response to these conservation incentives, several interviewees indicated that they tell their children they should not to hunt too many BBOP and should not cut trees unnecessarily, while they claim to act accordingly themselves.

In the Enga area two informal regulations with considerable influence on BBOP collection and trade exist, which both decrease local hunting pressure on the birds. First there is the 'Christian notion' that forbids the use of (B)BOP feathers, which was said to be adhered to by some, mainly Christian, interviewees. Priests and other Christians active in the Enga area have been speaking out against the traditional use of the feathers, and to a lesser extent against the hunting of the birds. Second, there is the 'kumul agreement' between a tourist lodge and several clan communities, which implies that these clans agreed not to hunt (B)BOP because tourists come to see these birds. However, this regulation seems to relocate (B)BOP collection to areas where this regulation does not apply. Table 6 presents the factors influencing the level of collection.

Almost all of the interviewees in the Tari research area suggested that the BBOP population is declining, while the majority in the Enga research area indicated that the BBOP population is stable or even increasing. Table 7 provides an overview of some (perceived) trends in BBOP collection.

In the remoter (Tari) research area, where no strong informal regulations exist, the BOP's economic and socio-cultural value appears to be more important, more interviewees suggested an increase in singsings, and (B)BOP feathers are regularly worn by men for no specific occasion. Notions of the bird's aesthetic value and pride related to the BBOP only exist in the non-remote communities. 
Table 6. Factors that influence collection quantities.

\begin{tabular}{|c|c|}
\hline Factors behind a decrease of collection & Factors behind an increase of collection \\
\hline $\begin{array}{l}\text { Conservation incentives; preserving birds } \\
\text { for future use, and increased appreciation } \\
\text { of, and sense of 'pride' associated with, the } \\
\text { presence of living birds }\end{array}$ & $\begin{array}{l}\text { Increased occurrence of traditional festivities } \\
\text { (singsings) where feathers are used; celebration } \\
\text { of Christmas, Independence day, and visits of } \\
\text { important politicians }\end{array}$ \\
\hline Tourists interested in bird watching & Tourists purchasing feathers \\
\hline Priests who forbid the use of the feathers & Increased use of guns \\
\hline Low population densities of BBOP & Informal regulations; the 'kumul agreement' \\
\hline Inhabitants' decreasing interest in traditions & seems to relocate (B)BOP collection \\
\hline $\begin{array}{l}\text { Informal regulations, such as the 'Christian notion' } \\
\text { and 'kumul agreement' }\end{array}$ & $\begin{array}{l}\text { to areas where this regulation does } \\
\text { not apply }\end{array}$ \\
\hline
\end{tabular}

In conclusion, the factors that decrease hunting pressure, as mentioned in Table 6, are more dominant in the less remote areas. While the factors that increase hunting pressure are more dominant in the remoter areas. Thus, market access and integration may decrease collection by the local inhabitants. Tourism, however, plays a double role. While bird-related tourism is on the increase, which creates a direct incentive to decrease hunting, general tourism may result in an increase in singsings (where the feathers play an important role) and the sale of the feathers to tourists. Similarly, the increasing influence of Christianity plays a double role; Christian priests forbid the use of BBOP, while - ironically- the celebration of Christmas results in an increase of singsings.

\section{Discussion}

\section{Awareness-raising as a conservation measure?}

Forest clearance for subsistence agriculture is a major cause of deforestation in PNG's more densely populated highlands and international commercial forestry is a major threat (Stattersfield et al. 1998, WWF 2009a,b, Bates in litt., Gregory in litt.). Conservation efforts are hindered by several factors, such as law and order problems, corruption, political instability, a high and increasing crime rate, and a lack of infrastructure (Osborne 1995, IPA 2009, UNAA 2009).

In PNG the BBOP is protected by law. The majority of the interviewees said they were aware of existing regulations, but indicated that these regulations have no influence on BBOP collection and trade, as the law is not enforced. Surprisingly, this view was shared by the Tari district officer and the policemen interviewed (Figure 3). Moreover, ideas about the content of conservation regulations differed among respondents. For instance, some thought it is illegal to hunt and trade BOP, while others thought it is illegal to hunt BOP, but legal to trade BOP. Some respondents doubted whether the BOP restrictions also apply to BBOP or only to the commonly used Raggiana Bird-of-paradise Paradisaea raggiana.

Effective BBOP conservation seems to depend largely on awareness-raising and education among local populations, for two reasons. Firstly, PNG's weak central government authority, a lack of law enforcement and law and order problems make collection and trade laws and

Table 7. (Perceived) trends (sample size: 100 respondents).

\begin{tabular}{lll}
\hline & Tari research area & Enga research area \\
\hline (Perceived) deforestation rate & + & + \\
Singsing trend & + & - \\
Collection trend & $+/-$ & - \\
(Perceived) BBOP population trend & - & + \\
\hline
\end{tabular}


regulations doomed to fail. Secondly, as $97 \%$ of PNG's land is owned by local inhabitants, who for a large part depend on these lands for their subsistence livelihoods (Gascoigne 1998, Armitage 2001, Motta et al. 2007), the establishment of strictly protected areas is hardly a realistic option. This is in line with the views of Sekhran and Miller (1996) and Sillitoe (2001) who stress the need to involve the inhabitants in the protection of PNG's flora and fauna.

Awareness-raising should address the risk of extinction. Interviews, especially in the less remote communities, showed that there is a sense of 'pride' and an aesthetic value associated with the presence of BBOP, which may serve as a good starting point. Inhabitants could be educated how to preserve the feathers in order to use them for as many years as possible; see Figure 4 . This could be combined with general awareness regarding the importance of the natural forest for both BBOP and the inhabitants' subsistence livelihoods. Awareness-raising in communities with high levels of market access and integration should primarily be focused on trade, while efforts to increase awareness regarding the effects of hunting should focus on the remoter communities, where most collection takes place.

Importantly, awareness-raising should not only target the inhabitants, but also visiting tourists, because the research showed that inhabitants regularly sell BBOP to tourists. Tourist and tourist operators should be made aware of the existing legislations.

Awareness-raising could be effectively and cheaply done through the use of informational posters, flyers and signs, educational talks, and also through education at schools. Locations for tourist-oriented campaigns could be Port Moresby international airport (PNG's only international airport) and other domestic airports, tourist lodges, and tourism agencies - and company offices. At the Mt. Hagen, Goroka and other cultural shows, both visiting tourists and participating inhabitants could be addressed.

\section{Future research}

More research should be conducted on the collection and trade of the BBOP in more areas and for longer periods of time, so that nationwide trends can be fully understood. Also, research is needed to better understand the effects of deforestation. BBOP observations and interviews during this research suggest that the bird's reported poor tolerance of habitat degradation (BirdLife International 2000, Bird in litt.) may be over-estimated (certainly with regards to foraging), which warrants a further investigation to verify or invalidate this statement. Lastly, more research is needed on the bird's population (distribution, density, size and trends) and reproduction rate. This combined research would help to better understand the ecological sustainability of collection and to determine hunting thresholds in particular areas.

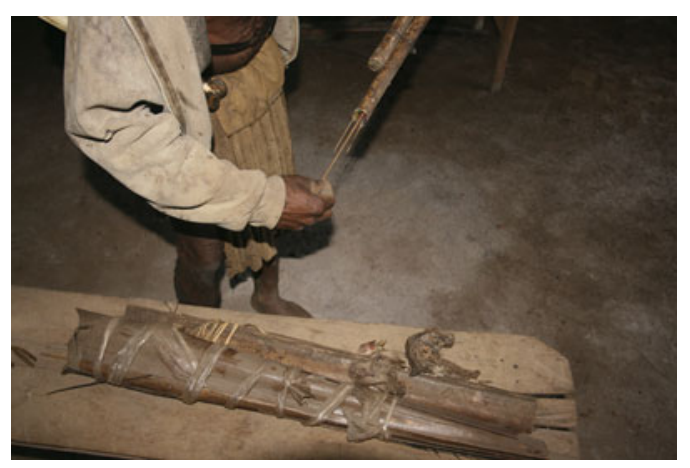

Figure 4. An inhabitant showing how he keeps his feathers secure in tubes to prevent the feathers from wearing out (Munima clan, Southern Highlands Province, PNG, June, 2008; Michiel O. L. van den Bergh). 


\section{Supplementary Material}

The online supplementary materials for this article can be found at journals.cambridge.org/bci

\section{Acknowledgements}

We thank Pius (Pi clan) and his family, and the Kumul lodge. We also thank all who provided comments on the research. Finally, many thanks to Sanja Paul from the Wizzy clan, who helped as an interpreter and research assistant.

\section{References}

Armitage, L. (2001) Customary land tenure in Papua New Guinea: Status and prospects. Brisbane, Australia: Queensland University of Technology. Available from: <http://dlc. dlib.indiana.edu/archive/oooo1043/oo/ armitage.pdf $>$ [Accessed Dec 2008].

Bank of Papua New Guinea (2009) Historical exchange rates [website]. Available from: $<$ http://www.bankpng.gov.pg/index.php? option=com_content\&task=view\&id=360\& Itemid $=275>$ [Accessed Jan 2009].

Beehler, B. M., Pratt, T. K. and Zimmerman, D. A. (1986) Birds of New Guinea. Princeton, NJ: Princeton University Press.

BirdLife International (200o) Threatened birds of the world. Barcelona, Spain and Cambridge, UK: Lynx Edicions and BirdLife International.

BirdLife International (2009) Blue Bird-ofparadise. BirdLife Species Factsheet. Available from: <http://www.birdlife.org/datazone/ species/index.html?action=SpcHTMDetails. asp\&sid $=5846 \& \mathrm{~m}=0>$ [Accessed Jan 2009].

CITES (2009) What is CITES? [website]. Available from: <http://www.cites.org/eng/ disc/what.shtml> [Accessed Jan 2009].

Connell, J. (1997) Papua New Guinea, The struggle for development. London, UK: Routledge.

del Hoyo, J., Elliott, A. and Christie, D. A., eds. (2009) Handbook of the birds of the world. Vol. 14. Bush-shrikes to Old World sparrows. Barcelona, Spain: Lynx Edicions.

Demmer, J. and Overman, H. (2001) Indigenous people conserving the rain forest? The effect of wealth and markets on the economic behaviour of Tawahka Amerindians in Honduras. Wageningen, The Netherlands: Tropenbos International. (Tropenbos Series 19).
Frith, C. B. and Beehler, B. M. (1998) The birds of paradise. New York: Oxford University Press, Inc.

Gascoigne, I. (1998) Cultures of the world. Papua New Guinea. 2nd Edition. New York, USA: Marshall Cavendish.

Goldman, L. (2003) Discussion paper: State society and governance in Melanesia [online]. Canberra:The Australian National University. Available from: $<$ http://dspace.anu.edu.au/ bitstream/I885/42124/I/goldman.pdf> [Accessed Feb 2009].

Gregory, C. A. (1981) A conceptual analysis of a non-capitalist gift economy with particular reference to Papua New Guinea. Cambridge J. Econ. 5(2).

Heads, M. (2002) Birds of paradise, vicariance biogeography and terrane tectonics in New Guinea. J. Biogeogr. 29: 261-283.

IPA (Investment Promotion Authority Papua New Guinea) (2009) Department of Environment and Conservation. Available from: <http://www.ipa.gov.pg/index.php? option $=$ com_content $\&$ task $=$ view $\&$ id $=182 \&$ Itemid $=128>$ [Accessed Jan 2009].

IUCN (2011) Paradisaea rudolphi. Available from: http://www.iucnredlist.org/apps/ redlist/details/106005846/o [Accessed Nov 2011].

Kwapena, N. (1984) Traditional conservation and utilization of wildlife in Papua New Guinea. The Environmentalist Vol. 4, Supplement 7: 22-26.

Lomas, G. C. J. (1998) The Huli people of Papua New Guinea. Available from: <http://www. gabelomas.org/huli/htms/huliı.htm> [Accessed Mar 2008].

Motta, S., Lyons, C. and Tiel van, A. (2007) Implementation of a land administration project: Papua New Guinea. Available from: 
<http://www.sli.unimelb.edu.au/subjects/ 451/418/groupreports2007/PapuaNewGuineaMajorAssignment.doc> [Accessed Feb 2009].

Osborne, P. L. (1995) Biological and cultural din Papua New Guinea: Conservation, conflicts, constraints and compromise. Ambio 24: 231-237.

Reillly, B. (2008) Ethnic conflict in Papua New Guinea. Asia Pacific Viewpoint 49(I): 12-22.

Sekhran, N. and Miller, S., eds. (1996) Рapua New Guinea country study on biological diversity. Waigani, Papua New Guinea: Papua New Guinea Department of Environment and Conservation.

Sillitoe, P. (2001) Hunting for conservation in the Papua New Guinea highlands. ETHNOS 66: 365-393.

Stattersfield, A., Crosby, M. J., Long, A. J. and Wege, D. C. (1998) Endemic bird areas of the world: priority for biodiversity conservation. Cambridge, UK: BirdLife International. (BirdLife Conservation Series no. 7).
Tumu, A., Munini, P., Kyangali, A. and Wiessner, P. (1989) A view of Enga culture. Madang, Papua New Guinea: KPI publishing. UNAA (United Nations Association of Australia) (2009) Papua New Guineaposition paper. Available from: $<\mathrm{http} / / / \mathrm{www}$. unaavictoria.org.au/media/RMIT \% 20 MUNC/Papua \% 20New\% 2oGuinea \% 20 Position \% 2oPaper \% 20- \% 20Katsuyuki \% 20 Matsumoto.pdf $>$ [Accessed Jan 2009].

WWF (2009a) New Guinea and islands indigenous landscape management initiative. World Wide Fund For Nature. Available from: <http://www.panda.org/about_wwf/ where_we_work/oceania/solutions_ country/papua_new_guinea/index. cfm? uProjectID=PGoo45> [Accessed Jan 2009].

WWF (2009b) Central Range montane rain forests (AA0105). World Wide Fund For Nature. Available from: $<$ http://www.worldwildlife. org/wildworld/profiles/terrestrial/aa/ aaO105_full.html> [Accessed Jan 2009].

\section{MICHIEL O. L. VAN DEN BERGH*, A. J. (TON) DIETZ}

The African Studies Centre, Wassenaarseweg 52, P.O. Box 9555, 2300 RB Leiden, The Netherlands.

\section{KOEN KUSTERS}

WiW - Global Research and Reporting, Eerste van Swindenstraat 391, 1093 GB, Amsterdam, The Netherlands.

*Author for correspondence; email: michielvdbergh@hotmail.com 